\title{
Loss of $\mathrm{K}-\mathrm{Cl}$ co-transporter $\mathrm{KCC} 3$ causes deafness, neurodegeneration and reduced seizure threshold
}

\section{Thomas Boettger ${ }^{1,2}$, Marco B.Rust ${ }^{1}$, Hannes Maier ${ }^{3}$, Thomas Seidenbecher ${ }^{4}$, Michaela Schweizer ${ }^{1}$, Damien J.Keating ${ }^{1}$, Jörg Faulhaber ${ }^{5}$, Heimo Ehmke ${ }^{5}$, Carsten Pfeffer ${ }^{1}$, Olaf Scheel ${ }^{1}$, Beate Lemcke $^{6}$, Jürgen Horst ${ }^{6}$, Rudolf Leuwer', Hans-Christian Pape ${ }^{4}$, Harald VölkI ${ }^{7}$, Christian A.Hübner ${ }^{1,8}$ and Thomas J.Jentsch ${ }^{1,9}$}

\author{
${ }^{1}$ Zentrum für Molekulare Neurobiologie, ZMNH, Universität \\ Hamburg, Falkenried 94, D-20251 Hamburg, ${ }^{3} \mathrm{HNO}$ Klinik, ${ }^{5}$ Institut \\ für Physiologie and ${ }^{8}$ Institut für Humangenetik, Universitätsklinikum \\ Eppendorf, Universität Hamburg, Martinistrasse 52, D-20246 \\ Hamburg, ${ }^{4}$ Institut für Physiologie, Medizinische Fakultät, Otto-von- \\ Guericke-Universität Magdeburg, Leipziger Strasse 44, D-39120 \\ Magdeburg, Germany, ${ }^{7}$ Institut für Physiologie der Universität \\ Innsbruck, Fritz-Pregl-Strasse 3, A-6010 Innsbruck, Austria and \\ ${ }^{6}$ Institut für Humangenetik, Universität Münster, Vesaliusweg 12-14, \\ D-48149 Münster, Germany \\ ${ }^{2}$ Present address: Martin-Luther-Universität Halle-Wittenberg, Zentrum \\ für medizinische Grundlagenforschung, Weinbergweg 22, D-06120 \\ Halle, Germany \\ ${ }^{9}$ Corresponding author \\ e-mail: Jentsch@zmnh.uni-hamburg.de
}

K-Cl co-transporters are encoded by four homologous genes and may have roles in transepithelial transport and in the regulation of cell volume and cytoplasmic chloride. $\mathrm{KCC} 3$, an isoform mutated in the human Anderman syndrome, is expressed in brain, epithelia and other tissues. To investigate the physiological functions of $\mathrm{KCC} 3$, we disrupted its gene in mice. This severely impaired cell volume regulation as assessed in renal tubules and neurons, and moderately raised intraneuronal $\mathrm{Cl}^{-}$concentration. $\mathrm{Kcc3}{ }^{-/-}$mice showed severe motor abnormalities correlating with a progressive neurodegeneration in the peripheral and CNS. Although no spontaneous seizures were observed, $\mathrm{Kcc}^{-/-}$ mice displayed reduced seizure threshold and spike-wave complexes on electrocorticograms. These resembled EEG abnormalities in patients with Anderman syndrome. $K c c 3^{-/-}$mice also displayed arterial hypertension and a slowly progressive deafness. $\mathrm{KCC} 3$ was expressed in many, but not all cells of the inner ear $\mathrm{K}^{+}$recycling pathway. These cells slowly degenerated, as did sensory hair cells. The present mouse model has revealed important cellular and systemic functions of $\mathrm{KCC} 3$ and is highly relevant for Anderman syndrome.

Keywords: ACCPN/blood pressure/KCC4/regulatory volume decrease/SlC12A6

\section{Introduction}

Cation-chloride co-transporters are encoded by a family of homologous mammalian genes and include the $\mathrm{Na}-\mathrm{Cl}$ cotransporter $\mathrm{NCC}$, the $\mathrm{Na}-\mathrm{K}-2 \mathrm{Cl}$ co-transporters $\mathrm{NKCC} 1$ and $\mathrm{NKCC} 2$, and the $\mathrm{K}-\mathrm{Cl}$ co-transporters $\mathrm{KCC} 1$ to KCC4. The stoichiometric coupling of cation and anion translocation results in an electrically silent, passive transport process driven by the transmembrane gradients of the respective ions. These transporters play important roles in the regulation of cytoplasmic ion concentrations and cell volume, as well as in salt transport across epithelia. Given the large inward gradient of $\mathrm{Na}^{+}$across the plasma membrane, the sodium-coupled NCC and NKCC proteins raise the intracellular chloride concentration $\left(\left[\mathrm{Cl}^{-}\right]_{\mathrm{i}}\right)$. Their role in transepithelial transport is evident from human inheritable diseases that result in the severe renal salt loss found in the Gitelman syndrome (NCC) (Simon et al., 1996b) and in Bartter's syndrome (NKCC2) (Simon et al., 1996a). In mice, the loss of NKCC1 leads to hearing loss, imbalance and infertility (Flagella et al., 1999).

The largest subgroup of cation-chloride co-transporters is formed by the $\mathrm{K}-\mathrm{Cl}$ co-transporters $\mathrm{KCCl}-4$ (Gillen et al., 1996; Payne et al., 1996; Hiki et al., 1999; Mount et al., 1999). By coupling $\mathrm{Cl}^{-}$transport to the inside-out $\mathrm{K}^{+}$ gradient, they mostly lower $\left[\mathrm{Cl}^{-}\right]_{\mathrm{i}}$ below its electrochemical equilibrium. $\mathrm{KCC} 1$ is widely expressed and has been implicated in many transport processes, including the regulatory volume decrease of erythrocytes. KCC2 is neuron specific. Antisense experiments (Rivera et al., 1999) and KCC2 knockout (KO) mice (Hübner et al., 2001) established a pivotal role of KCC2 in regulating $\left[\mathrm{Cl}^{-}\right]_{\mathrm{i}}$ in neurons. $\left[\mathrm{Cl}^{-}\right]_{\mathrm{i}}$ determines whether the neurotransmitters GABA or glycine are excitatory or inhibitory, because $\mathrm{GABA}_{\mathrm{A}}$ and glycine receptors are ligand-gated $\mathrm{Cl}^{-}$channels. KCC4 is mainly expressed in epithelial tissues and is activated $>100$-fold by swelling (Mount et al., 1999; Mercado et al., 2000). Loss of KCC4 led to deafness and renal tubular acidosis (Boettger et al., 2002), presumably due to a diminished removal of $\mathrm{K}^{+}$from sensory outer hair cells and to impaired $\mathrm{Cl}^{-}$extrusion from renal $\alpha$-intercalated cells, respectively. KCC 3 is expressed in the CNS and in numerous other tissues (Mount et al., 1999). KCC3 is active under isotonic conditions and can be further stimulated by hypotonic swelling (Race et al., 1999). In humans, KCC 3 mutations lead to agenesis of the corpus callosum with peripheral neuropathy (ACCPN or Anderman syndrome) (Howard et al., 2002; Dupré et al., 2003). The peripheral neuropathy of the disease was replicated in a KCC3 KO mouse model (Howard et al., 
A
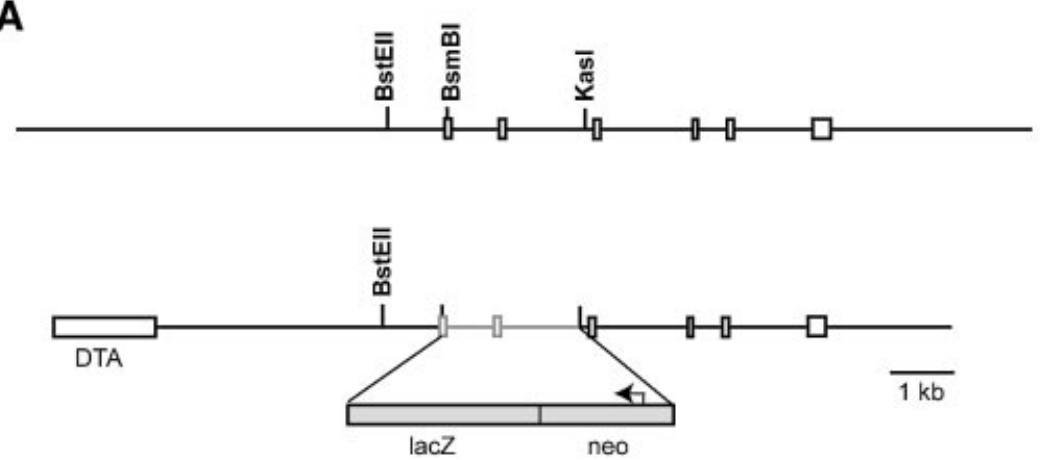

B

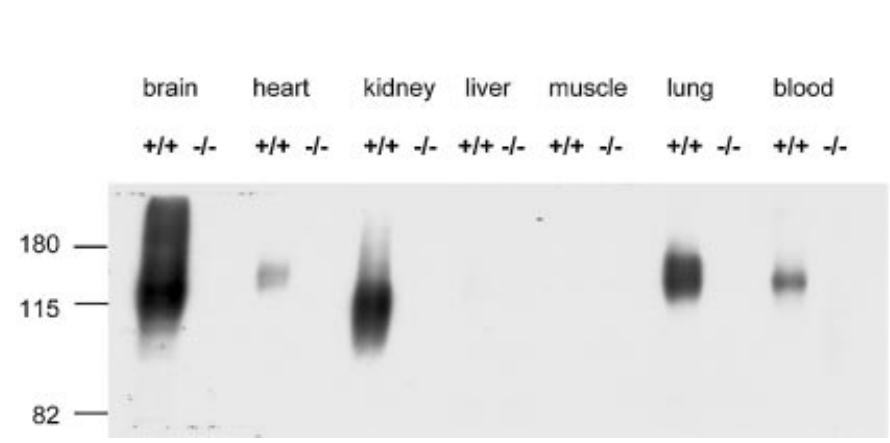

C

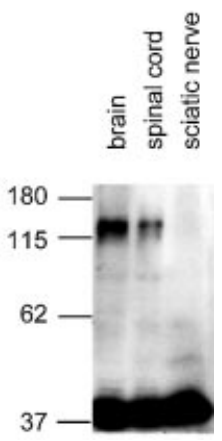

Fig. 1. Generation of $\mathrm{Kcc}^{-/-}$mice. (A) Partial representation of the genomic sequence of KCC3 (top) and construct used for the KO (bottom). A genomic stretch containing two coding exons was replaced by $\beta$-galactosidase (LacZ) and neomycin resistance cassettes. This deleted all KCC3 sequence after and including the first transmembrane domain and resulted in a KCC3- $\beta$-galactosidase fusion protein. The box at left represents a diphtheria toxin A (DTA) cassette to select for homologous recombination. (B) Western blot analysis of protein extracts from the indicated tissues from WT $(+/+)$ and KO $(-/-)$ mice. The difference in protein sizes may be due to alternative splicing. (C) Western blot analysis of protein extracts from brain, spinal cord and sciatic nerve. Actin (at bottom) served as loading control.

2002). However, this model lacked the morphological changes in the CNS that are typical of ACCPN.

We have generated a KCC3 KO mouse model that has revealed additional important phenotypes. The neurodegeneration of the present $K c c 3^{--}$mice affected not only peripheral nerves, but many other fibre tracts. The seizure susceptibility observed in ACCPN patients correlates with a decreased seizure threshold in $\mathrm{Kcc3}^{-/-}$mice. This may be related to abnormalities of the electrocorticogram (ECoG) in these mice, which resemble those of ACCPN patients. KCC3 is expressed in specific cell populations of the cochlear $\mathrm{K}^{+}$recycling pathway. Its disruption led to a slowly progressing deafness. Furthermore, $K c c 3^{-1-}$ mice have arterial hypertension. On a cellular level, we show that $\mathrm{KCC} 3$ is a key player in volume regulation of epithelial cells of the renal proximal tubule and of neurons. $\mathrm{KCC} 3$ lowers $\left[\mathrm{Cl}^{-}\right]_{\mathrm{i}}$ in neurons, albeit less than $\mathrm{KCC} 2$. The impaired volume regulation and an altered response to GABA due to a rise in $\left[\mathrm{Cl}^{-}\right]_{\mathrm{i}}$ are likely to contribute to the CNS excitability and neurodegeneration.

\section{Results}

\section{Disruption of the KCC3 gene in mice}

We disrupted the $K C C 3$ gene by fusing the first conserved exon that is present in all known splice variants in-frame to $\beta$-galactosidase. It was followed by stop codons and a neomycin selection cassette (Figure 1A). The construct predicts a cytoplasmic fusion protein from which the entire transmembrane portion and C-terminus of $\mathrm{KCC} 3$ are deleted. Western blot analysis confirmed the absence of $\mathrm{KCC} 3$ in all examined KO tissues (Figure 1B). This result also demonstrated the specificity of the antiserum.

$K c 3^{-/-}$mice were viable and fertile. They displayed severe neurological defects, slowly progressive hearing loss and hypertension. To correlate these phenotypes with the loss of $\mathrm{KCC} 3$, we first investigated its expression pattern.

\section{KCC3 is present in epithelial tissues and neurons}

LacZ staining of $\mathrm{Kcc}^{+/-}$embryos at day 14 (E14) revealed widespread transcription, in particular in epithelia (Figure 2A). RNA in situ hybridization of whole mice at post-natal day 0 (P0) (Figure 2B) showed strong expression of the KCC3 mRNA in the nervous system, including brain, spinal cord and dorsal root ganglia. The RNA was also present in various other tissues such as nasal epithelium, trachea, oesophagus, stomach, gut, lung, kidney and heart. LacZ staining showed broad expression in the brain (Figure 2C) and spinal cord (Figure 2F). Neurons in all hippocampal regions were intensely labelled (Figure 2D), as were neurons in dorsal root ganglia (Figure 2E). White matter tracts in the brain, including the corpus callosum (Figure 2C) and the spinal cord (Figure 2F), lacked lacZ staining. Analysis of KCC3 expression in the spinal cord by immunofluorescence 

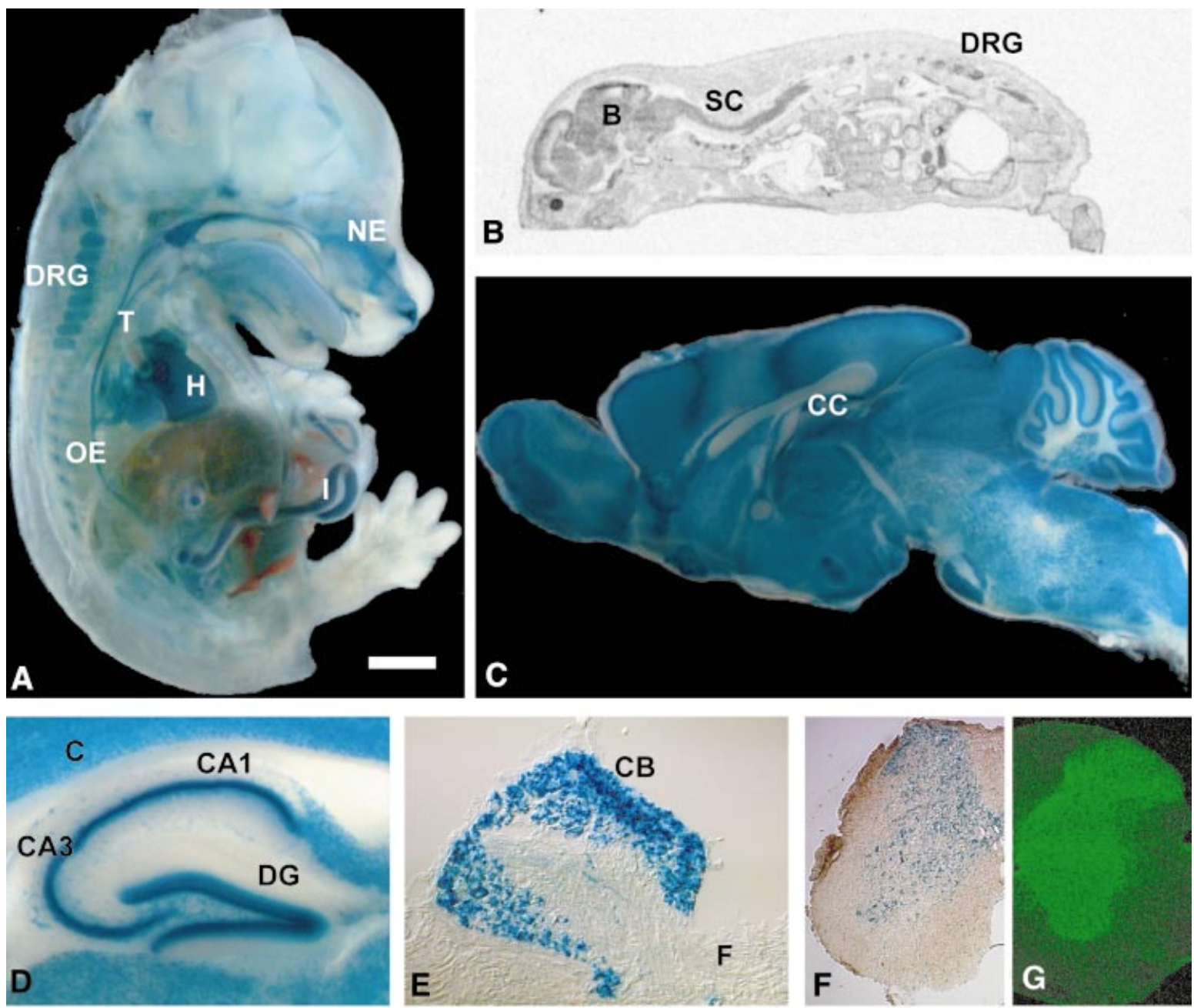

Fig. 2. Expression of KCC3. (A) lacZ staining of a $K c c 3^{+/-}$embryo at day 14 (E14). (B) In situ hybridization of a P0 mouse. LacZ staining of a sagittal brain section (C), hippocampus (D), a dorsal root ganglion $(\mathbf{E})$ and spinal cord $(\mathbf{F})$ from a $K c 3^{+/-}$mouse. (G) Immunofluorescence of spinal cord (B, brain; C, cortex, $\mathrm{CA} 1$ and $\mathrm{CA} 3$, cornu ammonis region 1 and 3; $\mathrm{CB}$, neuronal cell bodies; CC, corpus callosum; DRG, dorsal root ganglion; DG, dentate gyrus; F, fibres; NE, nasal epithelium; T, trachea; H, heart; I, intestine; OE, oesophagus; SC, spinal cord). The scale bar corresponds to $126 \mathrm{~mm}$ in (A), $33 \mathrm{~mm}$ in (B), $1.5 \mathrm{~mm}$ in (C), $0.44 \mathrm{~mm}$ in (D), $0.15 \mathrm{~mm}$ in (E), $0.39 \mathrm{~mm}$ in $(\mathrm{F})$ and $0.26 \mathrm{~mm}$ in $(\mathrm{G})$.

confirmed the neuronal labelling in the grey matter (Figure 2G). Immunoreactivity that emanated from the grey into the white matter co-localized preferentially with synaptic marker proteins (not shown).

Consistent with the lack of mRNA and lacZ expression in white matter tracts, the $\mathrm{KCC} 3$ antiserum stained neurons, but not glia. There was no co-staining with glial fibrillary acidic protein (GFAP) (Figure 3A) or myelin-associated glycoprotein (MAG) (Figure 3B). KCC3 was expressed in neuronal cell bodies (Figure 3C). In contrast to KCC2 (Figure 3D), which was found nearly exclusively in the plasma membrane (Hübner et al., 2001), KCC3 was also detected intracellularly (Figure 3C). $\mathrm{KCC} 3$ was present at synapses as shown by co-staining with synaptophysin (Figure 3E), VGLUT1 and Vamp1 (not shown). KCC3 staining overlapped only occasionally with neurofilament (Figure 3F) or MAP2 (Figure 3G), markers of axons and dendrites, respectively. The cotransporter was not associated with nerve fibres when sciatic nerve was assessed by either western blotting (Figure 1C) or immunofluorescence of longitudinal sections (not shown).

\section{Neurological phenotype}

Already at 3 weeks of age, $\mathrm{Kcc}^{-/-}$mice had motor and posture abnormalities. When lifted by the tail, they showed an abnormal hind limb grasp instead of the normal extension response. Sometimes, in particular in $\mathrm{KO}$ mice older than 1 year, this abnormal behaviour was also observed with their forelegs. Abnormal postures were also observed spontaneously. Mice sometimes showed grossly abnormal positions of their hind legs while sitting (Figure 4A), or sometimes lay flat on the ground (Figure 4B). Older mice often showed an inability to move their hind limbs.

Although no spontaneous seizures were observed, the latency until the onset of convulsions upon exposure to flurothyl was significantly shortened [wild type (WT), $140 \pm 6 \mathrm{~s} ; \mathrm{KO}, 106 \pm 7 \mathrm{~s} ; 20$ pairs; $P<0.0001$; mean age 3 months]. We therefore compared the ECoG of $\mathrm{Kcc}^{-1-}$ mice with WT littermates. WT ECoGs were very regular (8-10 Hz; Figure 4C and D), with a mean amplitude of $349 \pm 23 \mu \mathrm{V}$ and a mean predominant frequency of $6.7 \pm$ $1.8 \mathrm{~Hz}$. The ECoGs of $\mathrm{Kcc}^{---}$mice were characterized by an irregular wideband frequency range $(2-8 \mathrm{~Hz})$ and the 

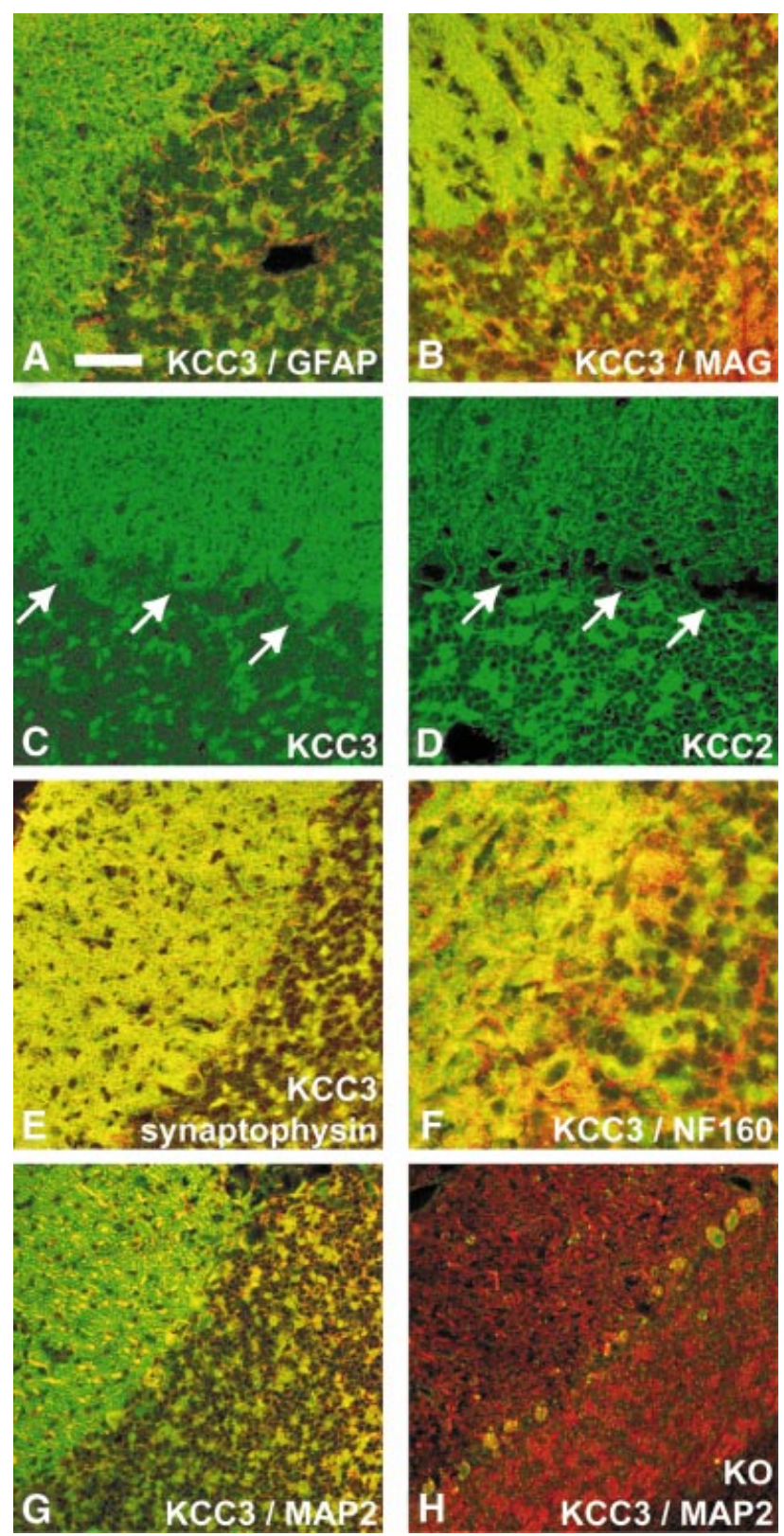

Fig. 3. Subcellular distribution of KCC3 in the cerebellum. There was no significant overlap of KCC3 staining (green) with the glial marker proteins GFAP (A) or MAG (B) (red). (C) KCC3 was present in the plasma membrane and cell interior of cerebellar Purkinje cells (arrows). (D) KCC2 was almost exclusively in the plasma membrane of Purkinje cells (arrows). (E) KCC3 staining (green) largely co-localized with synaptophysin (red), a marker for synapses. (F) Staining for KCC3 (green) and neurofilament (red), a marker for axons, overlapped rarely. This was also the case when KCC3 (green) is compared with MAP2 (red), a marker for dendrites $(\mathbf{G})$. (H) Staining for $\mathrm{KCC} 3$ of a $\mathrm{KO}$ mouse. The scale bar corresponds to $28 \mu \mathrm{m}$ in (A)-(E), $18 \mu \mathrm{m}$ in (F), and $39 \mu \mathrm{m}$ in $(\mathrm{G})$ and $(\mathrm{H})$.

occurrence of spontaneous high-voltage spike-and-wavelike complexes up to $700 \mu \mathrm{V}$ in amplitude (Figure $4 \mathrm{~F}$ and $\mathrm{G})$. The power spectrum of the ECoG was dominated by these events, with the peak at $4.8 \pm 1.5 \mathrm{~Hz}$. The peak frequencies were significantly $(P<0.05)$ different in WT and KO. In comparison with WT, the mean amplitude of the ECoG at $4 \mathrm{~Hz}$ was significantly increased (Figure 4I; $P<0.005)$.
These findings prompted us to examine EEGs in two patients with Anderman syndrome who are homozygous for a missense mutation truncating the $\mathrm{KCC} 3$ protein. The 7 and 9 year old brothers have had pathological EEG recordings for many years. They displayed recurrent sharp waves and sharp-slow-wave complexes (Figure 4J and K). No epileptic seizures have been observed so far.

\section{Neurodegeneration in the CNS and PNS}

Degeneration was found in many regions of the nervous system, in particular in the white matter. As recently described (Howard et al., 2002), there was a severe degeneration of the sciatic nerve that was already obvious at P13 (Figure 5C and D). Degeneration also affected the spinal cord (Figure 5G and $\mathrm{H}$ ), hippocampus (Figure 5I$\mathrm{N}$ ) and the cerebellum (Supplementary figure 1, available at The EMBO Journal Online). No degeneration was found in corresponding tissues of $\mathrm{P} 1$ mice, which showed normal development (Figure 5A, B, E and F). Analysis of ventral and dorsal roots of the spinal cord revealed that both motor and sensory nerves were affected (not shown). While the optic stalk degenerated, no retinal degeneration was detected. The corpus callosum showed no signs of degeneration either (Supplementary figure 1).

In the hippocampus, the degeneration was concentrated in the outer molecular layer of the dentate gyrus along the hippocampal fissure (Figure 5I-L). The vacuolization in this region was more severe at 3 months of age (Figure 5L) than at P13 (Figure 5J). No degeneration was observed at P1 (not shown).

A peculiarity of the degeneration was the vacuolization, and the presence of enlarged myelinated (Figure 5M) and unmyelinated (Figure 5N) axons. Synapses were found in degenerating hippocampal axons (Figure $5 \mathrm{~N}$ ), suggesting that they had established synaptic connections before degeneration. The related postsynaptic spines were normal in size and had well developed postsynaptic densities.

\section{Slowly progressive hearing loss}

As $\mathrm{Kcc}^{-1-}$ mice are deaf (Boettger et al., 2002), we examined the expression of $\mathrm{KCC} 3$ in the inner ear. Like $\mathrm{KCC} 4$, the KCC3 protein was present in the supporting cells of the inner and outer hair cells (IHCs and OHCs) (Figure 6A and B). In contrast to KCC4, KCC3 was also found in the other epithelial cells of the organ of Corti and was prominently expressed in type I and III fibrocytes that underlie the stria vascularis (Figure 6A). Counterstaining with Kir4.1, a K $\mathrm{K}^{+}$channel of intermediate cells (Ando and Takeuchi, 1999) (Figure 6C), or with barttin (not shown), a $\mathrm{Cl}^{-}$channel subunit present in marginal cells (Estévez et al., 2001), revealed a lack of $\mathrm{KCC} 3$ expression in either cell type. KCC3 was undetectable in type II fibrocytes.

Auditory brainstem responses showed that $\mathrm{Kcc}^{-{ }^{--}}$mice slowly lost their hearing over the first year (Figure 7A). The progression of deafness was much slower than in $K c c 4^{--}$mice (Boettger et al., 2002) and correlated with degenerative processes in the cochlea (Figure 6D and F). At 3 months of age, a degeneration of the organ of Corti was observed in two out of four animals. In older animals ( $\geqslant 5$ months), the organ of Corti was lost more frequently (12 out of 15 mice) and there was often a significant loss of type I and III fibrocytes. 

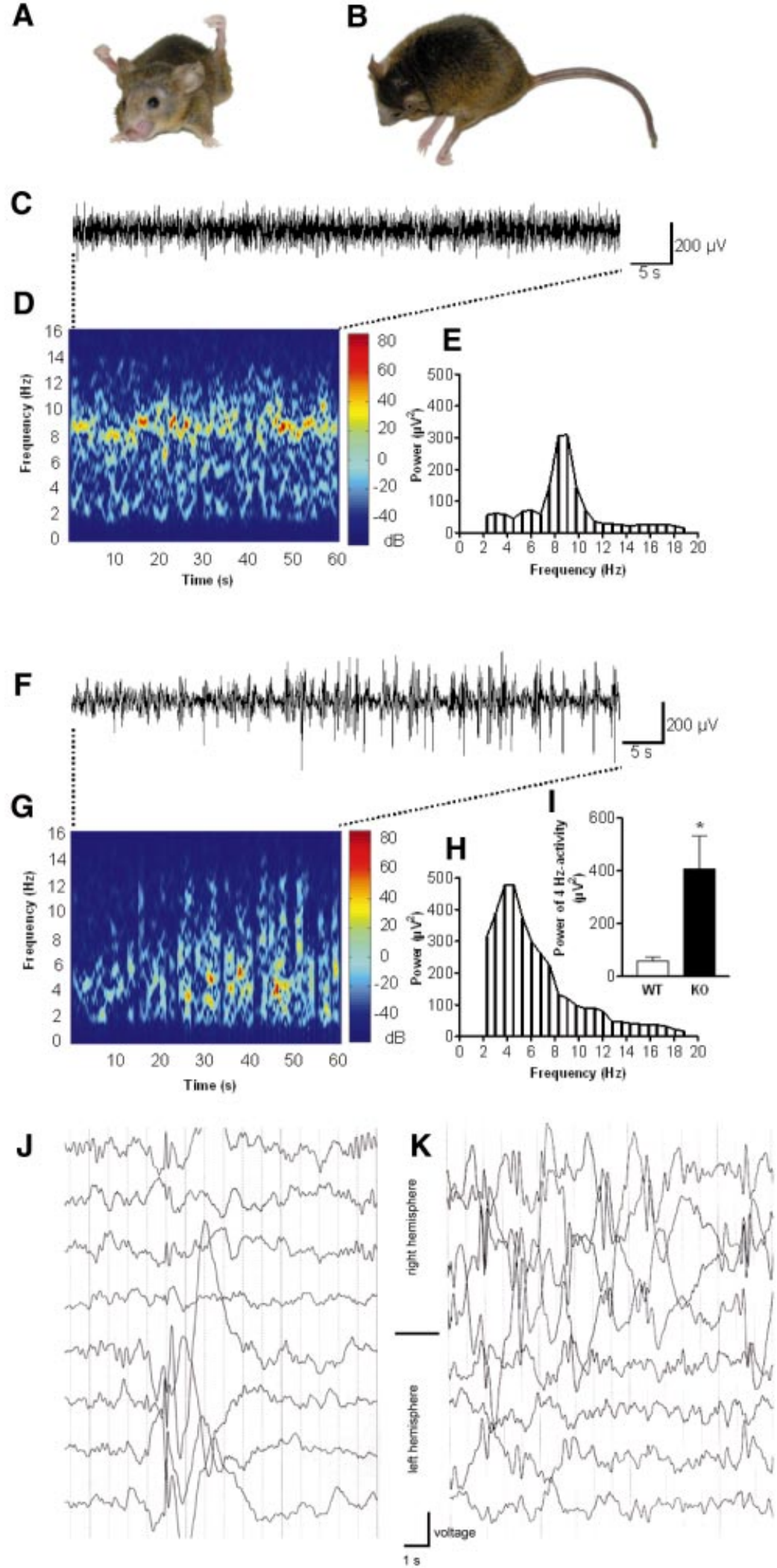

Fig. 4. Neuronal phenotype of $K c c 3^{-/-}$mice. (A) Abnormal posture of a 15-month-old KO mouse reminiscent of spasticity. (B) Another KO mouse lay flat on the ground. (C-I) ECoG analysis. Comparison of WT (C-E and I) and KO animals (F-I). (C) Original trace of field potential recording in a freely moving WT control. (D) Colour-coded power spectrum of the trace illustrated in (C). Note activity at 7-10 Hz. (E) Conventional fast Fourier transformation (FFT) of the trace in (C) indicates a predominant frequency at $7-10 \mathrm{~Hz}$. (F) Original trace in $\mathrm{KO}$ animal with spontaneous high-voltage spike-wave-like complexes. (G) Colour-coded power spectrum of the trace in (F). (H) Conventional FFT of this trace indicates a wideband frequency range with a peak at $4 \mathrm{~Hz}$. (I) Comparison of the power of the $4 \mathrm{~Hz}$ activity. KO mice $(n=6)$ showed a significantly higher power of the $4 \mathrm{~Hz}$ activity $(P<0.005)$ compared with WT $(n=6)$. ( $\mathbf{J}$ and $\mathbf{K})$ Electroencephalograms (EEGs) from two patients carrying a homozygous missense mutation in the KCC3 gene. 

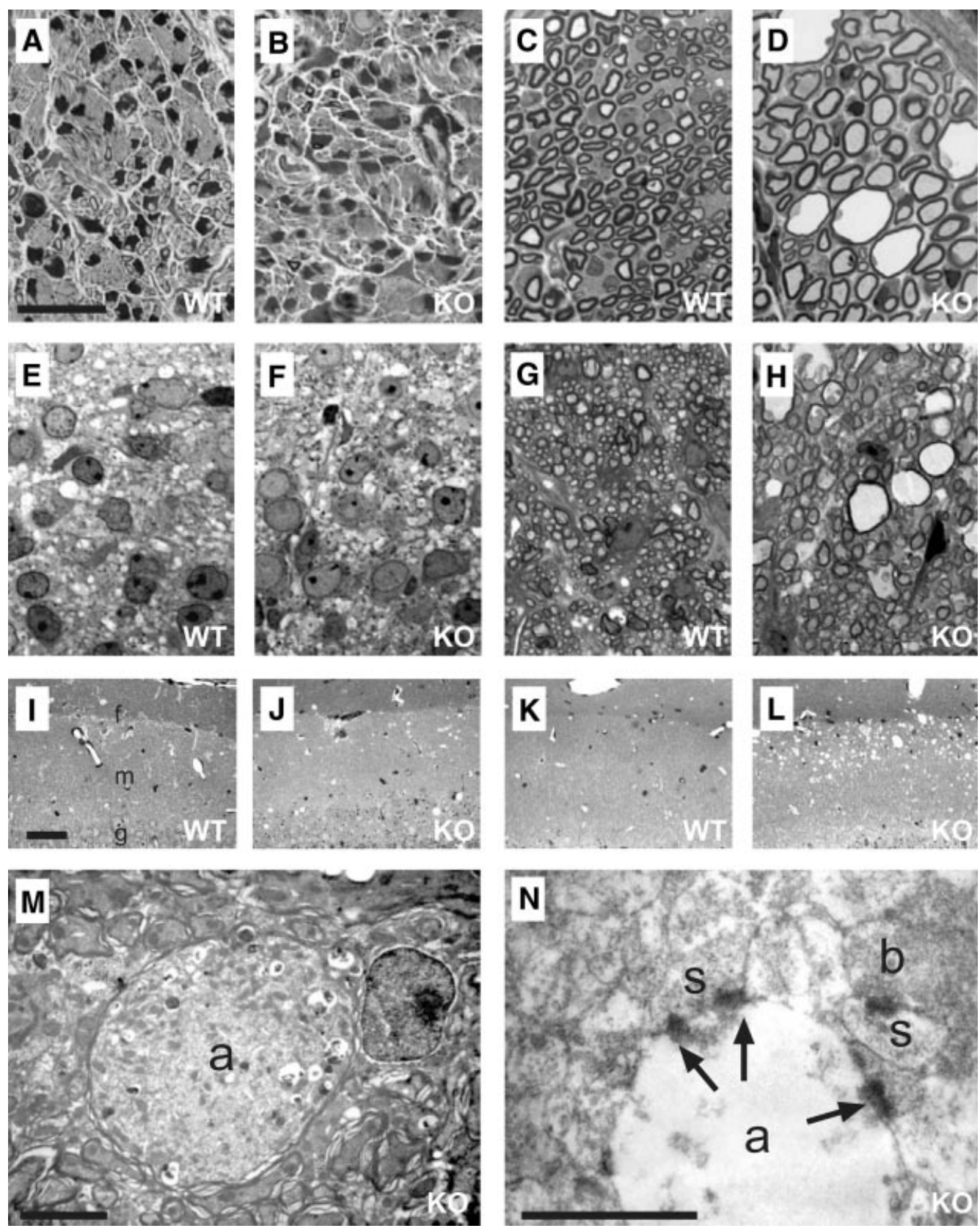

Fig. 5. Neurodegeneration in $K c c 3^{-/-}$mice. Semi-thin sections from sciatic nerve (A-D) and white matter of the spinal cord (E-H) at P1 (A, B, E and F) from WT (A, E, C and G) and KO (B, D, F and H) animals. (I-L) Semi-thin sections mainly of the molecular layer [m in (I); g, border of granular layer; f, hippocampal fissure] of hippocampal dentate gyrus from P13 (I and J) and 3 month (K and L) old animals. (M and N) Electron micrographs of swollen axons (a) in 3-month-old hippocampi. M, a myelinated axon filled with degradation product; N, a degenerated unmyelinated axon with synapses (arrows) terminating on morphologically intact spines (s). Intact axonal boutons (b) were present in the vicinity. The scale bar corresponds to: $20 \mu \mathrm{m}$ in $(\mathrm{A})-(\mathrm{H})$ and $(\mathrm{M}), 50 \mu \mathrm{m}$ in $(\mathrm{I})-(\mathrm{L})$ and $5 \mu \mathrm{m}$ in $(\mathrm{N})$.

Type II fibrocytes (lacking KCC3) were often preserved in KO mice that already displayed a severe loss of type I and III fibrocytes (which express KCC3) (Figure 6D). In older animals, neurons of the spiral ganglion had degenerated, probably secondary to a loss of hair cells (Figure 6D). The temporal relationship between the degeneration of fibrocytes and hair cells was variable. In most sections of the organ of Corti, OHCs and IHCs were either both present or both absent. However, there were a few examples where OHCs had degenerated while IHCs were still present (Figure 6F).
As the epithelial cells and fibrocytes that express KCC3 may transport $\mathrm{K}^{+}$in a recycling pathway (Kikuchi et al., 2000; Wangemann, 2002) (Figure 6G), we measured the endocochlear potential and $\mathrm{K}^{+}$concentration in the scala media in young ( $<75$ days) and old ( $>110$ days) mice. There was no significant difference between WT and KO in either age group (Figure 7B). A passive steady-state potential (SSP) can be measured after the elimination of active $\mathrm{K}^{+}$secretion some minutes after death. It depends on the difference in ionic composition of the endolymph and perilymph and on the permselectivity of the cell layers 

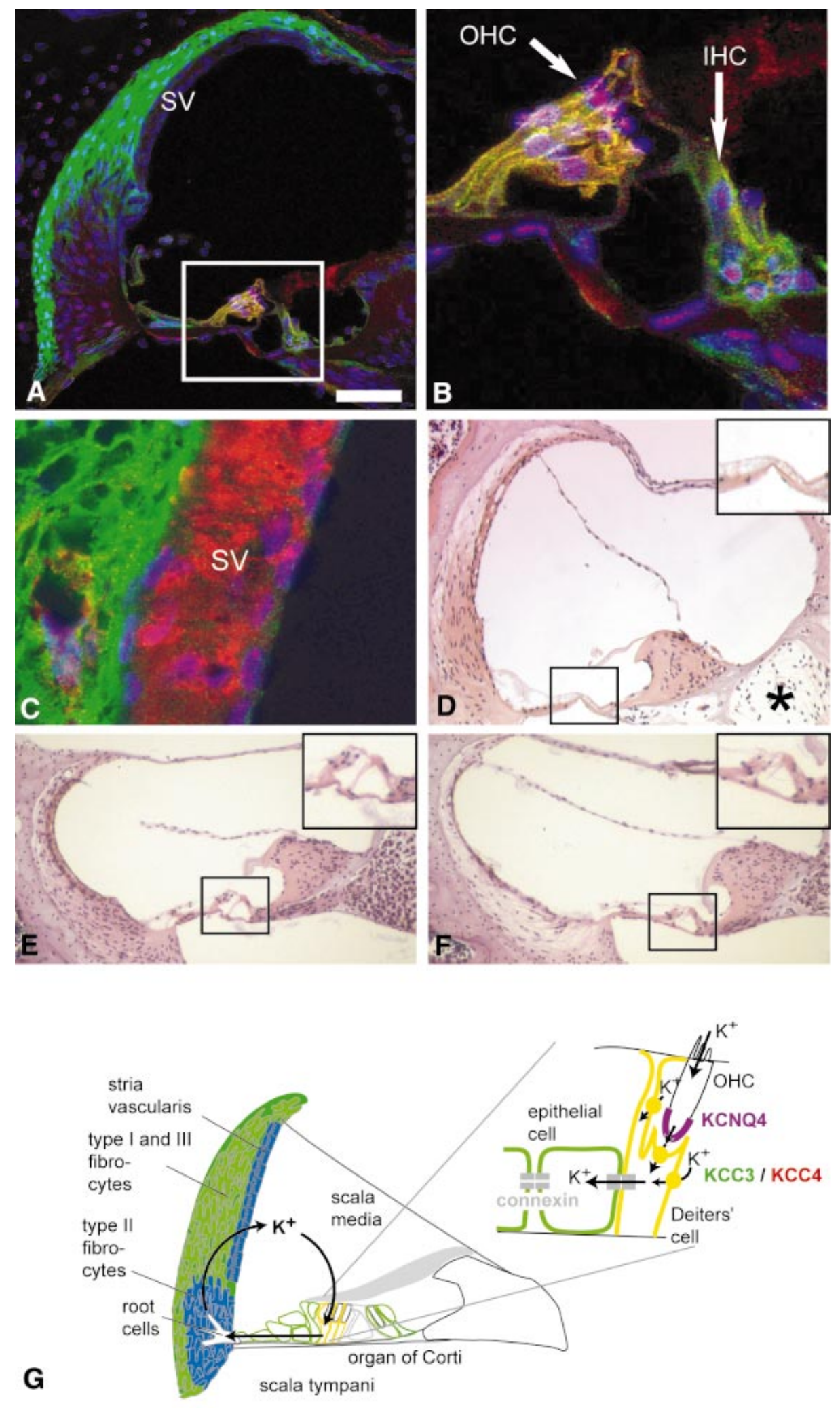

Fig. 6. Cochlear expression of KCC3 and morphological changes in the KO. (A) Staining for KCC3 (green) and KCC4 (red) in a cross-section of the scala media. KCC3 is found in type I and type III fibrocytes below the stria vascularis (SV), but not in type II fibrocytes. In the organ of Corti [enclosed by the frame and shown in higher magnification in (B)], KCC3 is in supporting cells of OHCs and IHCs and in additional epithelial cells. Supporting cells expressed both KCC3 and KCC4, yielding yellow (A, B and G). Nuclei were counterstained in blue. (C) Higher magnification of the stria vascularis and adjacent type I fibrocytes. KCC3 is shown in green and Kir4.1, a $\mathrm{K}^{+}$channel of intermediate cells, in red. (D) Haematoxylineosin-stained cross-section of a basal cochlear turn of a 15-month-old KO mouse. Note degeneration of type I and III and preservation of type II fibrocytes, loss of the organ of Corti (black frame; shown in higher magnification in upper right) and cell loss in the cochlear ganglion (*). Cross-sections through a basal turn of the cochlea of a 4-month-old WT (E) and KO mouse $(\mathbf{F})$. (G) Inner ear $\mathrm{K}^{+}$recycling pathway. KCC 3 is shown in green, coexpression with KCC4 in yellow, NKCC1 in blue and KCNQ4 in magenta. The scale bar corresponds to $50 \mu \mathrm{m}$ in $(\mathrm{A}), 14 \mu \mathrm{m}$ in $(\mathrm{B}), 9.4 \mu \mathrm{m}$ in $(\mathrm{C})$ and $100 \mu \mathrm{m}$ in (D)-(F). 

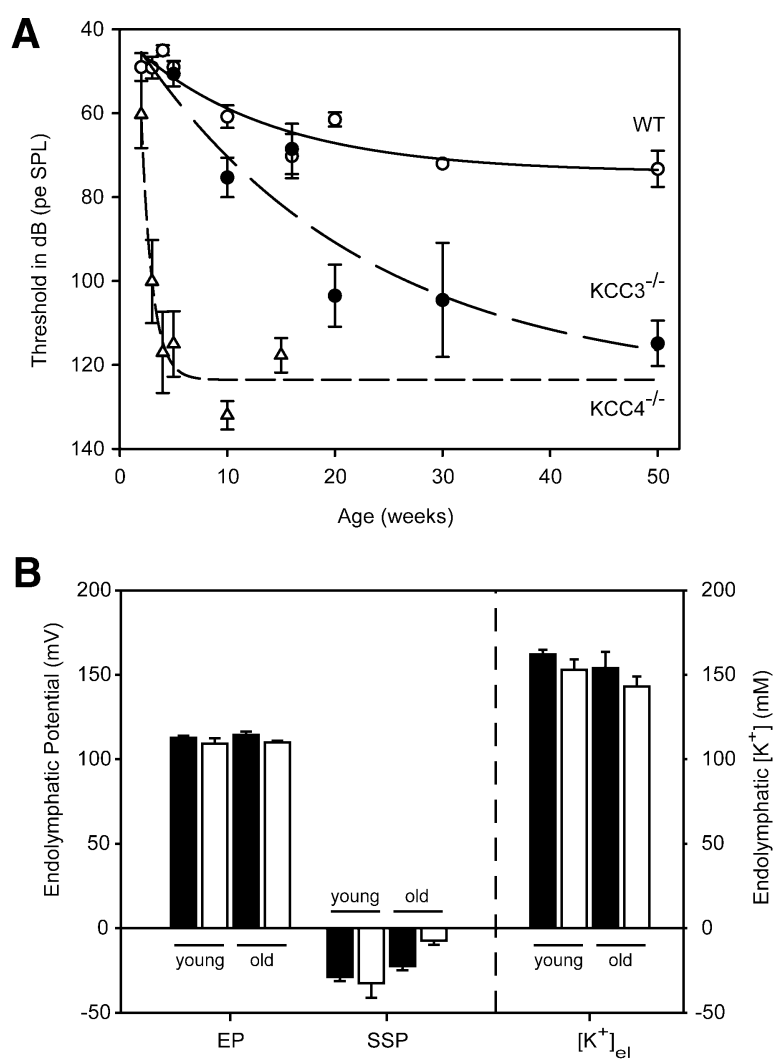

Fig. 7. Functional tests of the inner ear. (A) Thresholds of auditory brainstem responses to clicks in WT (open circles) and $\mathrm{Kcc}^{-1-}$ (filled circles) animals as a function of age. For comparison, published data from $\mathrm{Kcc}^{-1-}$ mice (Boettger et al., 2002) were included (open triangles). Bars indicate the standard error of seven or more animals. (B) EP, post mortem endocochlear SSP and endolymph $\mathrm{K}^{+}$concentration $\left(\left[\mathrm{K}^{+}\right]_{\mathrm{el}}\right)$ in young $(<75$ days) and old ( $>110$ days) WT (filled bar) or $\mathrm{Kcc}^{-/-}(\mathrm{KO}$; open bar) mice. Mean ages for young animals were 51 days (WT) and 39 days (KO), and for old mice 181 days (WT) and 204 days (KO). Only the SSP in old KO mice was significantly different from WT $(P<0.01)$. EP was measured in $13 \mathrm{WT}$ and eight KO animals, $\left[\mathrm{K}^{+}\right]_{\mathrm{el}}$ in nine WT and seven $\mathrm{KO}$ animals.

enclosing the scala media. Whereas there was no difference in young mice, the SSP was significantly decreased in old animals $[-22.4 \pm 3.1 \mathrm{mV}$ (WT) versus $-7.3 \pm 2.5 \mathrm{mV}$ (KO)] (Figure 7B).

\section{$\mathrm{Kcc3}^{-/-}$mice are hypertensive}

Arterial blood pressure was measured in awake, unrestrained 3- to 5-month-old male mice. Whereas WT mice had a mean pressure of $100 \pm 2 \mathrm{mmHg}$ (SEM, $n=6$ ), it was significantly $(P<0.0001)$ higher $(118 \pm 2 \mathrm{mmHg}, n=$ $5)$ in KO littermates. There was no difference in heart rates $(514 \pm 20$ and $510 \pm 31$ beats/min for WT and KO, respectively).

\section{Cell physiological roles of KCС : regulation of intracellular chloride and cell volume}

The neuronal isoform KCC2 is crucial for GABAergic synaptic inhibition by lowering $\left[\mathrm{Cl}^{-}\right]_{\mathrm{i}}$ of neurons (Rivera et al., 1999; Hübner et al., 2001). We wished to determine whether KCC3 plays a similar role. GABA responses of cerebellar Purkinje cells, which abundantly express KCC3 in addition to $\mathrm{KCC} 2$ (Figure 3), were investigated in slice preparations by gramicidin-perforated patch-clamp recordings that avoid an equilibration of $\left[\mathrm{Cl}^{-}\right]_{\mathrm{i}}$ with the pipette. In typical voltage-clamp experiments (Figure 8A and B) $100 \mu \mathrm{M} \mathrm{GABA}$ hyperpolarized the resting potential $(\mathrm{I}=0)$ from about -60 to $-80 \mathrm{mV}$ in $\mathrm{WT}$, but to only $-70 \mathrm{mV}$ in $\mathrm{KO}$ neurons (Figure 8A and B, respectively). Averaged GABA-induced voltage changes are shown in Figure 8C. In voltage-clamp experiments (left bars), $100 \mu \mathrm{M}$ GABA hyperpolarized WT cells by $-21.9 \pm$ $1.9 \mathrm{mV}$, but KO cells by only $-11.0 \pm 1.6 \mathrm{mV}$. Similar results were obtained in the current clamp mode [right bars; $\Delta \mathrm{V}=-22.5 \pm 2.9 \mathrm{mV}$ (WT) and $-11.2 \pm 1.4 \mathrm{mV}$ (KO)]. Neglecting the $\mathrm{HCO}_{3}{ }^{-}$permeability of $\mathrm{GABA}_{\mathrm{A}}$ receptors (Kaila and Voipio, 1987) and assuming that their $\mathrm{Cl}^{-}$currents dominate the conductance in the presence of GABA, we calculated that KCC3 lowers $\left[\mathrm{Cl}^{-}\right]_{\mathrm{i}}$ from $\sim 8.3 \mathrm{mM}$ (KO) to $5.6 \mathrm{mM}$ (WT).

As KCC 3 is stimulated by cell swelling (Race et al., 1999), we investigated whether the regulatory volume decrease (RVD) is impaired in KO neurons. When the osmolarity was decreased to $230 \mathrm{mM}$, the volume of WT and KO neurons increased by $\sim 15 \%$ (Figure $8 \mathrm{D}$ ). Whereas WT cells recovered their volume within $\sim 20$ min, the RVD of $\mathrm{Kcc}^{-/-}$was severely reduced.

We also studied epithelial cells of the kidney, which prominently expresses KCC3 (Figure 1B). Immunofluorescence stained $\mathrm{KCC} 3$ in basolateral membranes of proximal tubules, but not in other nephron segments (Supplementary figure 2). These membranes also express KCC4 (Boettger et al., 2002), which is also activated by swelling. We compared RVD in isolated perfused proximal straight tubules of WT, $\mathrm{Kcc}^{3^{--}}$and $\mathrm{Kcc}^{\mathrm{H}^{--}}$ mice. Upon exposure to hypotonicity, their cell volume increased by $\sim 10 \%$. Cells from WT tubules regained their initial volume in $<3 \mathrm{~min}$ (Figure 8E). In contrast, $\mathrm{Kcc}^{-/-}$ cells reversed only about half of their initial volume increase within this time. RVD was less impaired in $\mathrm{Kcc4}^{-/-}$mice.

\section{Discussion}

The disruption of the $\mathrm{K}-\mathrm{Cl}$ co-transporter $\mathrm{KCC} 3$ in mice led to several, in part surprising, phenotypes. The impairment of regulatory cell volume decrease in $\mathrm{Kcc}^{-{ }^{--}}$mice showed that the stimulation of KCC3 by cell swelling observed in heterologous expression (Race et al., 1999) is physiologically important. Furthermore, patch-clamping revealed that $\mathrm{KCC} 3$ contributes to a low $\mathrm{Cl}^{-}$concentration in neurons. The degeneration in the PNS and CNS and in the inner ear was unexpected, as was the arterial hypertension. The degeneration of many cells may be a cellautonomous consequence of defective cell volume regulation, but the deafness and abnormalities in cortical electrical activity may instead be due to changed intra- and extracellular ion concentrations. As was shown recently (Howard et al., 2002), mutations in human KCC3 lead to peripheral neuropathy associated with agenesis of the corpus callosum (ACCPN or Anderman syndrome). While the peripheral neuropathy of the human disease was replicated in the $\mathrm{Kcc}^{-3^{--}}$mice presented by Howard et al. (2002), no CNS degeneration, alteration in ECoGs, deafness, hypertension or changes in $\left[\mathrm{Cl}^{-}\right]_{\mathrm{i}}$ and cell volume regulation were reported. In addition to revealing 

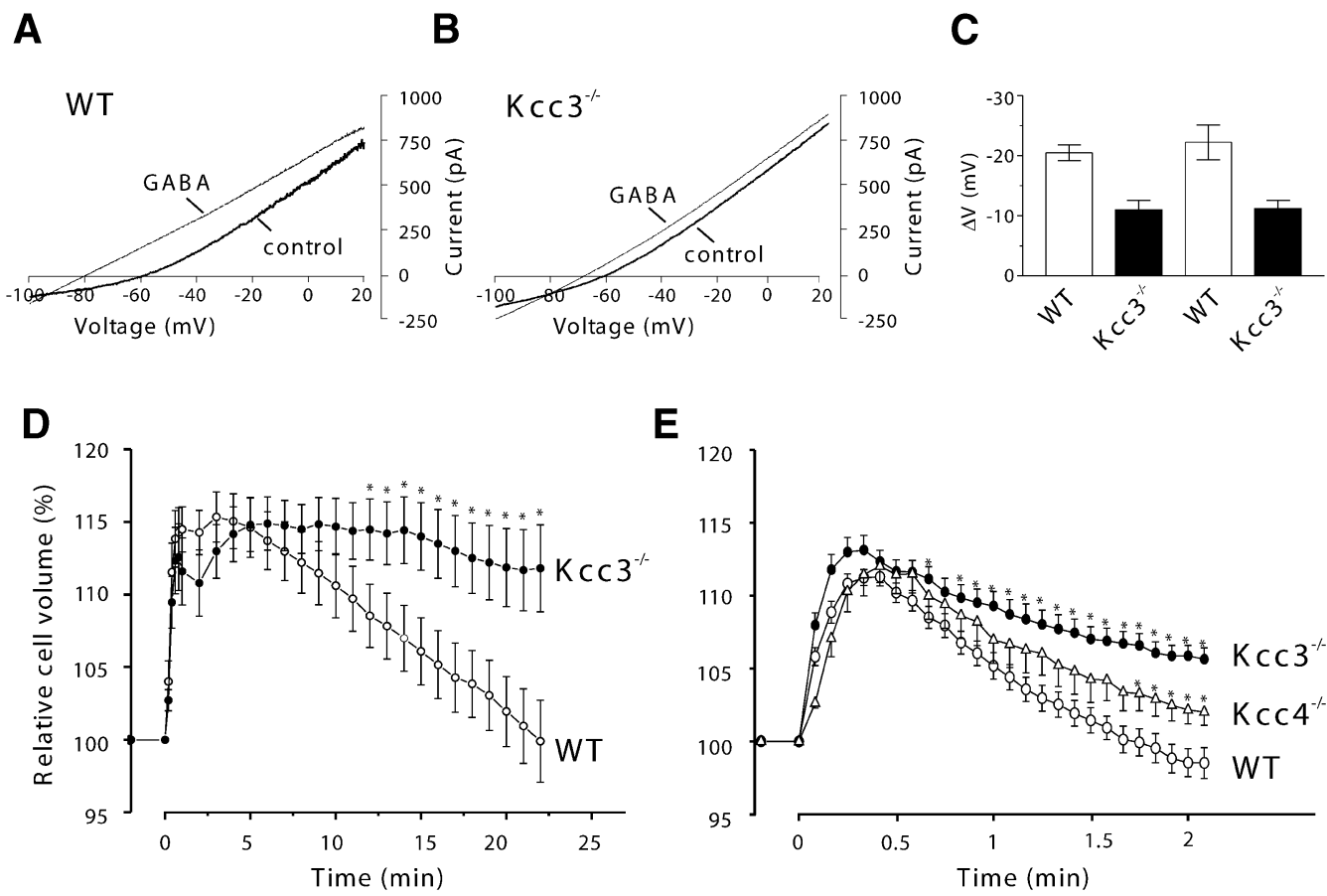

Fig. 8. Cell physiological effects of deleting KCC3. (A-C) Changes in neuronal $\left[\mathrm{Cl}^{-}\right]_{\mathrm{i}}$ studied by perforated patch-clamp measurements of P12-P14 Purkinje cells. Representative I-V relationships of WT (A) and $\mathrm{Kcc}^{-1-}$ (B) Purkinje cells measured in voltage-clamp before (thick line) and after (thin line) applying $100 \mu \mathrm{M}$ GABA. From $-60 \mathrm{mV}$, cells were stepped for $80 \mathrm{~ms}$ to $+20 \mathrm{mV}$ and the voltage was reduced to $-100 \mathrm{mV}$ with a voltage ramp $(150 \mathrm{mV} / \mathrm{s})$. (C) Mean shift in voltage ( \pm SEM) upon GABA application in either voltage clamp (first two bars) or current clamp mode of WT or KO cells. From the left, $n=4,4,8$ and 6 . The differences in GABA-induced hyperpolarization were significant at the $P<0.05$ level in either recording mode. The resting potentials were not significantly different between WT $(-59.4 \pm 1.7 \mathrm{mV})$ and $\mathrm{KO}(-60.0 \pm 0.9 \mathrm{mV})$. (D and E) Cell volume regulation of cultured hippocampal pyramidal cells (D) and renal proximal tubular cells (E) of WT (open circles) and $K c c 3^{-/-}$(filled circles) mice. (E) also includes data from $\mathrm{Kcc}^{-l_{-}}$(open triangles) mice. Cells were exposed to hypoosmotic medium $(230 \mathrm{mosmol} / \mathrm{l})$ at $t=0$. Cell volume is expressed as a percent of the volume at $t=0$. Error bars indicate SEM and asterisks significant differences from the WT $(P<0.05)$. The numbers of measurements were: (D) $13 \mathrm{KO}$ and $12 \mathrm{WT}$ cells from four animals; (E) $\mathrm{Kcc}^{-/-}, 22$ tubules from six mice; $\mathrm{Kcc}^{-{ }^{--}}, 10$ tubules from five mice; WT, 30 tubules from 11 mice.

novel functions of $\mathrm{KCC} 3$, the present mouse model has important medical implications.

\section{Regulation of cell volume by KCC3}

Probably every mammalian cell regulates its volume in response to osmotic stress (O’Neill, 1999). Cell swelling in response to hypotonicity is reversed by RVD, which involves the cellular loss of organic osmolytes and $\mathrm{K}^{+}$and $\mathrm{Cl}^{-}$. The efflux of $\mathrm{K}^{+}$and $\mathrm{Cl}^{-}$can occur through separate swelling-activated $\mathrm{K}^{+}$and $\mathrm{Cl}^{-}$channels, or through directly coupled K-Cl co-transport (O'Neill, 1999). Except for KCC2, all KCC isoforms have been proposed to have a role in RVD (Race et al., 1999; Mercado et al., 2000).

We have shown in two very different cell types that KCC3 plays a major role in RVD. Since RVD may be relevant for neurodegeneration, hippocampal neurons were chosen as their culture is well characterized. Proximal tubules (PTs) were examined because they prominently express $\mathrm{KCC} 3$ and are an established system for studying RVD in a semi-intact tissue (O'Neill, 1999). In both cell types, disrupting KCC3 severely impaired RVD. Although KCC4 was more drastically activated by cell swelling than KCC3 in heterologous expression (Race et al., 1999; Mercado et al., 2000), KCC3 dominated RVD in the PT (Figure 8E). In addition to $\mathrm{KCC} 3$, neurons express $\mathrm{KCC} 2$ and possibly $\mathrm{KCC} 1$. However, $\mathrm{KCC} 2$ is thought to be insensitive to cell swelling, and the expression pattern and function of KCC1 in the CNS is currently unknown. Thus, KCC3 may be more important for neuronal than for PT RVD.

PT cells regulated their volume much faster than hippocampal neurons, possibly because they face larger osmotic challenges in vivo. $\mathrm{K}-\mathrm{Cl}$ co-transport is not thought to contribute significantly to transepithelial transport in the PT, but may protect these cells from swelling upon an increased urinary load of solutes that are reabsorbed in the PT. Accordingly, we did not observe changes in urinary parameters of $\mathrm{Kcc}^{-{ }^{--}}$mice and no histological changes were found in KO PTs (not shown).

\section{Seizure threshold and electrocorticogram: possible relationship to intraneuronal chloride and neurodegeneration}

Although we did not observe spontaneous seizures in $\mathrm{Kcc}^{---}$mice, their seizure threshold was reduced. ECoGs of freely moving animals revealed increased irregular electrical activity that included spontaneous high-voltage spike-and-wave-like complexes. Similar complexes were also observed in patients with Anderman syndrome. These complexes are typical of certain forms of human epilepsy, such as generalized absence epilepsy, and are mostly attributed to abnormal, synchronized activity in thalamocortical circuits (Steriade et al., 1994; McCormick and 
Contreras, 2001; Crunelli and Leresche, 2002). Various experimental models of absence epilepsy have indicated that $\mathrm{Cl}^{-}$-dependent synaptic inhibition mediated via $\mathrm{GABA}_{\mathrm{A}}$ receptors in thalamic (Staak and Pape, 2001) and neocortical (Timofeev et al., 2002) networks is critically involved in the generation of spike-wave seizures (reviewed by Crunelli and Leresche, 2002).

By regulating the cytoplasmic $\mathrm{Cl}^{-}$concentration $\left(\left[\mathrm{Cl}^{-}\right]_{\mathrm{i}}\right), \mathrm{K}-\mathrm{Cl}$ co-transport is crucial for synaptic inhibition. Postsynaptic $\mathrm{GABA}_{\mathrm{A}}$ and glycine receptors are ligand-gated anion channels the electrical response of which is determined by the electrochemical $\mathrm{Cl}^{-}$gradient. A major role in lowering intraneuronal $\left[\mathrm{Cl}^{-}\right]$, which is needed for synaptic inhibition, is played by the neuronal isoform $\mathrm{KCC} 2$, which is upregulated during development. KCC2 knock-down in vitro (Rivera et al., 1999) or its disruption in mice (Hübner et al., 2001) suppressed the developmental decrease in neuronal $\left[\mathrm{Cl}^{-}\right]_{\mathrm{i}} \cdot \mathrm{Kcc2}^{-{ }_{-}}$mice could not breathe. Their spasticity was due to an increased motoneuron activity resulting from a rise in $\left[\mathrm{Cl}^{-}\right]_{\mathrm{i}}$. Mice in which KCC2 expression was largely decreased, albeit not abolished, survived for a few weeks and had epileptic seizures (Woo et al., 2002).

While KCC2 may be the key regulator of neuronal $\left[\mathrm{Cl}^{-}\right]_{\mathrm{i}}$, the neuronal and often synaptic expression of KCC3 suggested a similar role. As deduced from a decreased hyperpolarization of KO Purkinje cells in response to GABA, $\left[\mathrm{Cl}^{-}\right]_{\mathrm{i}}$ was indeed higher in $\mathrm{Kcc}^{-1-}$ than in WT neurons. Compatible with a dominant role of $\mathrm{KCC} 2$, the GABA-response remained hyperpolarizing and thus inhibitory in $\mathrm{Kcc}^{3^{--}}$Purkinje cells. Although it involves a comparison of different cells and developmental stages, it is worth mentioning that the present $\sim 10 \mathrm{mV}$ shift in $\mathrm{Cl}^{-}$ equilibrium potential of P13 $\mathrm{Kcc}^{-/-}$Purkinje cells was less than the $\sim 20 \mathrm{mV}$ shift of $K c c 2^{-/-} \mathrm{P} 0$ motoneurons (Hübner et al., 2001).

The impact of $\mathrm{KCC} 3$ on $\left[\mathrm{Cl}^{-}\right]_{\mathrm{i}}$ may increase upon neuronal cell swelling caused by changes in ion concentrations elicited by intense neuronal activity. Under isotonic conditions, $\mathrm{KCC} 3$ transport activity may be rather low. For instance, dorsal root ganglia express $\mathrm{KCC} 3$ (Figure 2A and E) and KCC4 (not shown), but lack significant KCC2 expression (Hübner et al., 2001). Their electrical response to GABA is excitatory, suggesting a low transport activity of both $\mathrm{KCC} 3$ and $\mathrm{KCC} 4$.

The altered CNS excitability in the KO may thus be due to decreased synaptic inhibition caused by increased neuronal $\left[\mathrm{Cl}^{-}\right]_{\mathrm{i}}$. In view of the widespread neurodegeneration, excitability might also be influenced by structural changes.

\section{Neurodegeneration in the CNS and PNS}

A recently described KCC3 mouse model displayed peripheral neurodegeneration, but no morphological changes were detected in brain or spinal cord (Howard et al., 2002). In contrast, the present mouse model revealed a similarly severe neurodegeneration in the PNS and in several areas of the CNS. The observed morphological changes are not due to an impaired development, since the degeneration occurred postnatally. The progressive neurodegeneration was correlated with the increasing severity of the motor phenotype of $\mathrm{Kcc}^{-/-}$mice. The analysis of sciatic nerves and ventral and dorsal roots of the spinal cord indicated that axons of both motoneurons and sensory neurons degenerated. However, no alterations were seen in the grey matter in semi-thin sections of the spinal cord. This may be due to difficulties in detecting a moderate loss of cell bodies in this densely packed area.

As KCC 3 was reported to be expressed in glia (Pearson et al., 2001), Howard et al. (2002) hypothesized the PNS degeneration to be secondary to glial dysfunction, without, however, proposing a specific mechanism. In our immunocytochemical analysis glia lacked detectable KCC3 signals, whereas neurons were prominently labelled. Likewise, there was no significant LacZ expression in fibre tracts, including the spinal cord and the corpus callosum, and western analysis of peripheral nerve gave negative results. We conclude that neurodegeneration was not secondary to a loss of KCC3 on glia, but might represent a cell autonomous effect. It may relate to the severe impairment of neuronal RVD, with a possible contribution of the CNS hyperexcitability. Epilepsy often entails neurodegeneration, and neurons that have largely lost the ability to regulate their volume may be particularly vulnerable and sensitive to the changes in ion concentrations that occur during increased neuronal activity.

\section{$\mathrm{K}$-Cl co-transport, $\mathrm{K}^{+}$recycling and deafness}

The disruption of either KCC4 (Boettger et al., 2002) or KCC3 (this work) caused deafness via degenerative processes. The hearing loss developed much more rapidly with a loss of KCC4, although its expression in the adult cochlea is restricted to supporting cells that also express $\mathrm{KCC} 3$. It is not clear whether the more severe effect of KCC4 disruption on the organ of Corti was due to a higher expression of KCC4 in these cells or to different properties of these isoforms.

The apical mechanosensitive cation channels of sensory hair cells function as $\mathrm{K}^{+}$channels. To enable $\mathrm{K}^{+}$influx, the endolymph of the scala media has a high $\mathrm{K}^{+}$concentration $(\sim 150 \mathrm{mM})$ and a positive potential $(\sim 100 \mathrm{mV})$, both generated by the stria vascularis. A large proportion of $\mathrm{K}^{+}$ ions secreted by this epithelium is thought to be derived from ions entering hair cells from the endolymph in a recycling pathway (Kikuchi et al., 2000; Wangemann, 2002). In this model (Figure 6G), $\mathrm{K}^{+}$leaving OHCs through KCNQ4 $\mathrm{K}^{+}$channels (Kubisch et al., 1999; Kharkovets et al., 2000) is taken up by supporting Deiters' cells through KCC4 (Boettger et al., 2002). Deiters' cells are connected to root cells in the spiral ligament by an epithelial gap junction system, which provides a cytoplasmic route for $\mathrm{K}^{+}$diffusion. After exiting from root cells to the extracellular space, $\mathrm{K}^{+}$is taken up by type II fibrocytes. These are coupled to type I and III fibrocytes in a fibrocyte gap junction system that also includes the basal and intermediate cells of the stria vascularis. $\mathrm{K}^{+}$leaving intermediate cells is then taken up by marginal cells and is secreted through apical $\mathrm{K}^{+}$channels.

$\mathrm{KCC} 3$ could mediate $\mathrm{K}^{+}$uptake into supporting cells, as postulated for KCC4 (Figure 6G). This uptake could occur close to equilibrium, thereby avoiding energy expenditure and metabolic stress on the organ of Corti. After having left root cells, $\mathrm{K}^{+}$is accumulated by type II fibrocytes through $\mathrm{NKCC} 1$ and the $(\mathrm{Na}, \mathrm{K})$-ATPase (Kikuchi et al., 2000). Type II cells express NKCC1, but not KCC3, and the reverse is true for type I and III fibroblasts. This may 
create a $\mathrm{K}^{+}$gradient within the fibrocyte gap junction system. The exit into the space between intermediate and marginal cells of the stria occurs through Kir4.1 $\mathrm{K}^{+}$ channels (Ando and Takeuchi, 1999). This electrogenic exit generates the endocochlear potential. If KCC3 were expressed in type II fibrocytes or strial intermediate cells, its transport activity would interfere with $\mathrm{K}^{+}$recycling and the generation of the endocochlear potential (EP), respectively.

Whereas the KCC3 expression pattern is compatible with $\mathrm{K}^{+}$recycling, $\mathrm{KCC} 3$ is dispensable for strial $\mathrm{K}^{+}$ secretion because young $\mathrm{KO}$ mice heard normally and because EP and endolymph $\mathrm{K}^{+}$concentration $\left(\left[\mathrm{K}^{+}\right]_{\mathrm{el}}\right)$ were unchanged. Hence, KCC3 is either not crucial for $\mathrm{K}^{+}$ recycling, or the stria does not critically depend on recycling because it has access to other sources of $\mathrm{K}^{+}$.

Similar to $K c c 4^{-/-}$mice, $K c c 3^{-/}$mice had normal hearing thresholds at $\mathrm{P} 14$. Hence neither $\mathrm{K}-\mathrm{Cl}$ co-transporter per se is essential for hearing. Deafness apparently resulted from a degeneration of sensory hair cells that express neither $\mathrm{KCC} 3$ nor $\mathrm{KCC} 4$. As postulated for $K c c 4^{-1-}$ mice, hair cells may degenerate because of a changed ionic environment. Type I and III fibrocytes, in contrast, may die in a cell autonomous manner, possibly related to defective RVD, as they often disappeared earlier than type II fibrocytes, which are devoid of KCC3.

\section{Implications for human disease}

As described recently (Howard et al., 2002), KCC3 is mutated in ACCPN, a human autosomal recessive disease characterized by progressive sensorimotor neuropathy with mental retardation, dysmorphic features and variable agenesis of the corpus callosum. A recently described mouse model (Howard et al., 2002) and the present study revealed peripheral neurodegeneration as in the human disease. Both mouse models failed to reveal morphological changes in the corpus callosum, suggesting that its agenesis in humans may be unrelated to neurodegeneration. This conclusion is bolstered by the clinical observation that the severity and time-course of peripheral neuropathy did not correlate with the very variable degree of agenesis of the corpus callosum (Mathieu et al., 1990).

In contrast to the mice reported by Howard et al. (2002), the present mouse model showed neuronal degeneration in several fibre tracts of the CNS. Whereas Howard et al. stated that their mice were not deaf, our mice had a progressive hearing loss. Because of its slow progression, the deafness may have escaped the attention of those authors. It is unclear whether the apparent lack in CNS degeneration in their mice is caused by differences in their $\mathrm{KO}$ construct or is due to differences in genetic background.

The new phenotypes discovered in the present ACCPN mouse model have important clinical implications. The observed CNS degeneration may explain the mental retardation in affected individuals, and the changes in seizure threshold and ECoGs may reflect the seizures and EEG activity seen in some patients (Shapira and Cohen, 1973; Dupré et al., 2003). Indeed, the two patients included in this study had spike-and-wave activity that resembled $\mathrm{KO}$ mouse ECoGs. In contrast to the mouse, brainstem-evoked audiometry for both patients did not show significant hearing impairment. Given the slow development of deafness in $K c c 3^{-/-}$mice, however, these patients may have been too young to display significant hearing loss. It will be important to investigate whether patients develop arterial hypertension similar to $\mathrm{Kcc}^{-/-}$ mice. The pathogenesis of this hypertension is unclear. It may relate to the neurodegeneration or to an influence of $\mathrm{KCC} 3$ on $\left[\mathrm{Cl}^{-}\right]_{\mathrm{i}}$ of vascular smooth muscle in which it is expressed. A detailed investigation of this phenotype is in progress and beyond the scope of the present study.

In summary, the novel phenotypes of the present $\mathrm{Kcc}^{-1-}$ mouse have firmly established a role of $\mathrm{KCC} 3$ in the regulation of cell volume and of cytoplasmic $\mathrm{Cl}^{-}$concentration, and have revealed unexpected roles in the nervous system, inner ear and cardiovascular system. $\mathrm{Kcc3^{-1- }}$ mice provide a valuable mouse model for a human disease and suggest the presence of additional symptoms in ACCPN patients.

\section{Materials and methods}

\section{Disruption of $\mathrm{Kcc3}$}

A $\beta$-Gal/neomycin cassette replaced a BsmBI-KasI $2.2 \mathrm{~kb}$ genomic KCC3 fragment. This fused the $\beta-G a l$ open reading frame (ORF) to the ORF of Kcc3 in the supposed 95 bp third exon of KCC3 and deleted the downstream 132 bp exon. RNA splicing over the insert would generate a frameshift. Mouse lines were from two independent targeted MPI2 embryonic stem-cell clones. Studies were performed in a mixed 129SV/ C57B16 background and on animals backcrossed for four to six generations into C57B16 using littermates as controls.

\section{Antibodies}

Polyclonal antibodies were raised against a peptide (NSNYEEGDEYFDKNL) from the KCC3 N-terminus. Analysis of $\mathrm{KO}$ tissues in western blotting and immunofluorescence demonstrated their specificity (Figures $1 \mathrm{~B}$ and 3). We also used polyclonal antisera against KCC4 (Boettger et al., 2002), barttin (Estévez et al., 2001), Kir4.1 (Ando and Takeuchi, 1999), and monoclonal antibodies against synaptophysin (Sigma; S5768), MAP2 (Chemicon; MAB3418), NF160 (Sigma; N5264), MAG (Chemicon; MAB1567) and GFAP (Sigma; G3893). Secondary antibodies were from Molecular Probes or Jackson.

\section{Morphology}

Mouse kidney and inner ear sections and immunocytochemistry were carried out as described previously (Boettger et al., 2002). X-Gal staining was essentially as in Howard et al. (2002). Semi-thin and ultrathin sections were done and analysed as described previously (Stobrawa et al., 2001).

\section{Auditory brainstem response, endocochlear voltage and $\left[\mathrm{K}^{+}\right]$} Auditory brainstem responses were measured as described previously (Boettger et al., 2002). To measure endocochlear parameters, the bulla of mice anaesthetized with Rompun/Ketanest was laterally opened, leaving the tympanic membrane intact. The bone over a first turn of the cochlea was thinned and opened below the stapedial artery. A double-barrelled microelectrode was inserted and voltage and $\mathrm{K}^{+}$potentials measured against an $\mathrm{Ag} / \mathrm{AgCl}$ reference electrode in a salt bridge that was inserted under the skin. $\mathrm{K}^{+}$-selective barrels used liquid $\mathrm{K}^{+}$ionophore (Fluka, 60398) and were calibrated before and after experiments.

\section{Determination of RVD}

Proximal straight tubules. Segments $(0.5-1 \mathrm{~mm})$ from WT, $K c c 3^{-1-}$ and $\mathrm{Kcc}^{-/-}$mice were perfused at $>10 \mathrm{nl} / \mathrm{min}$ as described previously (Völkl and Lang, 2001). The lumen perfusate contained (in mM): $120 \mathrm{NaCl}, 5$ $\mathrm{KCl}, 20 \mathrm{NaHCO}_{3}, 1.3 \mathrm{CaCl}_{2}, 1 \mathrm{MgCl}_{2}, 2 \mathrm{Na}_{2} \mathrm{HPO}_{4}$ and 5 mannitol; and the isotonic bath perfusate ( $308 \mathrm{mosmol} / \mathrm{l}): 80 \mathrm{NaCl}, 5 \mathrm{KCl}, 20 \mathrm{NaHCO}_{3}$, $1.3 \mathrm{CaCl}_{2}, 1 \mathrm{MgCl}_{2}, 2 \mathrm{Na}_{2} \mathrm{HPO}_{4}, 1$ glucose, 1 Na-lactate, 2 L-glutamine and 80 mannitol. The hypoosmotic solution (230 mosmol/l) lacked mannitol. Bath solutions were gassed with $95 \% \mathrm{O}_{2} / 5 \% \mathrm{CO}_{2}$ to $\mathrm{pH} 7.4$ and heated to $38^{\circ} \mathrm{C}$. Digital images were acquired at intervals of $5 \mathrm{~s}$ using a CCD camera (SensiCam, PCO) and a 400× Nomarski optic (ICM 405, Zeiss). The mean outer radius $(r)$ and cell height $(h)$ were determined 
using Optimas software (Media Cybernetics). Apparent cell volume per unit tubule length $(V)$ was calculated from:

$$
V=\pi\left[r^{2}-(r-h)^{2}\right]=\pi\left(2 r h-h^{2}\right)
$$

and is expressed in fractions of the apparent volume prior to swelling $\left(V_{0}\right)$.

Neurons. Hippocampal neurons of P1 mice were cultured for 6 days on glass coverslips coated with laminin/poly-L-lysine essentially as described previously (Goslin and Banker, 1991). Cells were fluorescently labelled by a 30 min incubation with calcein-AM (Molecular Probes). Coverslips were rinsed, placed in a superfusion chamber on a Zeiss Axiophot microscope and superfused at room temperature with isotonic solution (in mM: $135 \mathrm{NaCl}, 1 \mathrm{CaCl}_{2}, 1.2 \mathrm{MgCl}_{2}, 1.7 \mathrm{KH}_{2} \mathrm{PO}_{4}, 5 \mathrm{KCl}, 5$ glucose, $10 \mathrm{HEPES}$, pH 7.4; $300 \mathrm{mosm} / \mathrm{l}$ ) followed by a hypotonic medium ( $230 \mathrm{mosm} / 1,85 \mathrm{mM} \mathrm{NaCl})$. Calcein fluorescence was excited at $470 \mathrm{~nm}$ and recorded at $>510 \mathrm{~nm}$ using a $\times 100$ lens (Zeiss) and a CCD camera (C4742-95, Hamamatsu). Cell areas were determined by setting intensity thresholds using Openlab Imaging Software (Improvision). Approximate relative volumes of pyramidal cells were calculated by taking the $3 / 2$ power of these areas. Mean values \pm SEM are given. Statistical analysis was performed using the $t$-test.

\section{Patch-clamping of cerebellar Purkinje cells}

Parasagittal slices $(300 \mu \mathrm{m})$ from cerebella of 12- to 14-day-old mice were prepared using a vibratome (Leica). Gramicidin-perforated patchclamp measurements were performed on Purkinje cells essentially as described previously for motoneurons (Hübner et al., 2001). TTX (500 nM) was added during agonist application in voltage-clamp recordings to exclude network effects.

\section{Determination of seizure threshold}

Seizure thresholds were determined by exposing animals to increasing concentrations of 2,2,2-trifluoroethyl ether (Aldrich) (Prichard et al., 1969; Bösl et al., 2001). Experiments were stopped with the first clear signs of seizure activity, such as myoclonic jerks of the head or extremities.

\section{Electrocorticograms}

Experiments were performed on 12 male mice (6-10 weeks old). Following anaesthesia with pentobarbital $(50 \mathrm{mg} / \mathrm{kg}$ intraperitoneally), mice were positioned in a stereotaxic instrument with bregma and lambda in a horizontal plane. For bilateral epidural ECoG recordings, silver electrodes were positioned over the central region (AP $-1.0 \mathrm{~mm}, \mathrm{~L} 2 \mathrm{~mm}$ from bregma) of both hemispheres and fixed. Reference and ground electrodes were implanted over the nasal and cerebellar region, respectively. The electrode ensemble was fed through a socket and fixed with dental cement. ECoG was recorded after 3 days under freely moving conditions using a swivel connector. ECoG analysis used the Spike2 software package (Cambridge Electronic Design) and Matlab (Mathworks). Signals were processed by a differential amplifier (EXT$20 \mathrm{~F}$ or DPA 2F; npi electronic), band-pass filtered at 0.3 and $100 \mathrm{~Hz}$, converted by an A/D interface (CED 1401plus; Cambridge Electronic Design) and stored on a PC. Data are shown as mean \pm SEM. Statistical analysis was performed using Student's $t$-test. $P$ values $<0.05$ were considered significant.

\section{Blood pressure measurements}

Cardiovascular studies were carried out in awake, unrestrained male mice (body weight 25 to $33 \mathrm{~g}$; age 3-5 months). Chronic catheters were implanted as described previously (Just et al., 2000). Arterial blood pressure and heart rate were determined for $1 \mathrm{~h}$ on day 2 and/or day 3 after surgery.

\section{Patients}

The homozygous 3031C $\rightarrow$ T change leading to a stop at amino acid 1011 in two affected children from a consanguineous Turkish family was described previously (Howard et al., 2002). These boys are small for their age (7 and 9 years) and are mentally retarded. Computed tomography scans revealed a complete agenesis of the corpus callosum. Nerve conduction velocity and amplitude was decreased. Walking was only possible over short distances.

\section{Supplementary data}

Supplementary data are available at The EMBO Journal Online.

\section{Acknowledgements}

We thank M.Kolster, B.Dierkes and I.Bösch for technical assistance, and S.Takeuchi for the antibody against Kir4.1. This work was supported by the Deutsche Forschungsgemeinschaft to T.J.J. and C.A.H., and the Ernst Jung Preis für Medizin to T.J.J.

\section{References}

Ando,M. and Takeuchi,S. (1999) Immunological identification of an inward rectifier $\mathrm{K}^{+}$channel (Kir4.1) in the intermediate cell (melanocyte) of the cochlear stria vascularis of gerbils and rats. Cell Tissue Res., 298, 179-183.

Boettger,T., Hübner,C.A., Maier,H., Rust,M.B., Beck,F.X. and Jentsch,T.J. (2002) Deafness and renal tubular acidosis in mice lacking the K-Cl co-transporter Kcc4. Nature, 416, 874-878.

Bösl,M.R., $\quad$ Stein,V., Hübner,C., $\quad$ Zdebik,A.A., Jordt,S.E., Mukhopadhyay,A.K., Davidoff,M.S., Holstein,A.F. and Jentsch,T.J. (2001) Male germ cells and photoreceptors, both dependent on close cell-cell interactions, degenerate upon $\mathrm{ClC}-2 \mathrm{Cl}^{-}$channel disruption. EMBO J., 20, 1289-1299.

Crunelli,V. and Leresche,N. (2002) Childhood absence epilepsy: genes, channels, neurons and networks. Nat. Rev. Neurosci., 3, 371-382.

Dupré,N., Howard,H.C., Mathieu,J., Karpati,G., Vanasse,M., Bouchard,J.P., Carpenter,S. and Rouleau,G.A. (2003) Hereditary motor and sensory neuropathy with agenesis of the corpus callosum. Ann. Neurol., 54, 9-18.

Estévez,R., Boettger,T., Stein,V., Birkenhäger,R., Otto,E., Hildebrandt,F. and Jentsch,T.J. (2001) Barttin is a $\mathrm{Cl}^{-}$channel $\beta$ subunit crucial for renal $\mathrm{Cl}^{-}$reabsorption and inner ear $\mathrm{K}^{+}$secretion. Nature, 414, 558-561.

Flagella,M. et al. (1999) Mice lacking the basolateral Na-K-2Cl cotransporter have impaired epithelial chloride secretion and are profoundly deaf. J. Biol. Chem., 274, 26946-26955.

Gillen,C.M., Brill,S., Payne,J.A. and Forbush,B.,III (1996) Molecular cloning and functional expression of the $\mathrm{K}-\mathrm{Cl}$ cotransporter from rabbit, rat and human. A new member of the cation-chloride cotransporter family. J. Biol. Chem., 271, 16237-16244.

Goslin,K. and Banker,G. (1991) Culturing Nerve Cells. MIT Press, Cambridge, MA.

Hiki,K., D'Andrea,R.J., Furze,J., Crawford,J., Woollatt,E., Sutherland,G.R., Vadas,M.A. and Gamble,J.R. (1999) Cloning, characterization and chromosomal location of a novel human $\mathrm{K}^{+}-\mathrm{Cl}^{-}$ cotransporter. J. Biol. Chem., 274, 10661-10667.

Howard,H.C. et al. (2002) The $\mathrm{K}-\mathrm{Cl}$ cotransporter $\mathrm{KCC} 3$ is mutant in a severe peripheral neuropathy associated with agenesis of the corpus callosum. Nat. Genet., 32, 384-392.

Hübner,C.A., Stein,V., Hermans-Borgmeyer,I., Meyer,T., Ballanyi,K. and Jentsch,T.J. (2001) Disruption of KCC2 reveals an essential role of $\mathrm{K}-\mathrm{Cl}$ cotransport already in early synaptic inhibition. Neuron, 30, $515-524$.

Just,A., Faulhaber,J. and Ehmke,H. (2000) Autonomic cardiovascular control in conscious mice. Am. J. Physiol., 279, R2214-R2221.

Kaila,K. and Voipio,J. (1987) Postsynaptic fall in intracellular pH induced by GABA-activated bicarbonate conductance. Nature, 330, $163-165$.

Kharkovets,T., Hardelin,J.P., Safieddine,S., Schweizer,M., ElAmraoui,A., Petit,C. and Jentsch,T.J. (2000) KCNQ4, a K' channel mutated in a form of dominant deafness, is expressed in the inner ear and the central auditory pathway. Proc. Natl Acad. Sci. USA, 97, $4333-4338$.

Kikuchi,T., Adams,J.C., Miyabe,Y., So,E. and Kobayashi,T. (2000) Potassium ion recycling pathway via gap junction systems in the mammalian cochlea and its interruption in hereditary nonsyndromic deafness. Med. Electron Microsc., 33, 51-56.

Kubisch,C., Schroeder,B.C., Friedrich,T., Lütjohann,B., El-Amraoui,A., Marlin,S., Petit,C. and Jentsch,T.J. (1999) KCNQ4, a novel potassium channel expressed in sensory outer hair cells, is mutated in dominant deafness. Cell, 96, 437-446.

Mathieu,J., Bédard,F., Prévost,C. and Langevin,P. (1990) Neuropathie sensitivo-motrice héréditaire avec ou sans agénésie du corps calleux: étude radiologique et clinique de 64 cas. Can. J. Neurol. Sci., 17, 103108.

McCormick,D.A. and Contreras,D. (2001) On the cellular and network bases of epileptic seizures. Annu. Rev. Physiol., 63, 815-846. 
Mercado,A., Song,L., Vazquez,N., Mount,D.B. and Gamba,G. (2000) Functional comparison of the $\mathrm{K}^{+}-\mathrm{Cl}^{-}$cotransporters $\mathrm{KCC} 1$ and $\mathrm{KCC} 4$. J. Biol. Chem., 275, 30326-30334.

Mount,D.B., Mercado,A., Song,L., Xu,J., George,A.L.,Jr, Delpire,E. and Gamba,G. (1999) Cloning and characterization of KCC3 and KCC4, new members of the cation-chloride cotransporter gene family. J. Biol. Chem., 274, 16355-16362.

O'Neill,W.C. (1999) Physiological significance of volume-regulatory transporters. Am. J. Physiol., 276, C995-C1011.

Payne,J.A., Stevenson,T.J. and Donaldson,L.F. (1996) Molecular characterization of a putative $\mathrm{K}-\mathrm{Cl}$ cotransporter in rat brain. A neuronal-specific isoform. J. Biol. Chem., 271, 16245-16252.

Pearson,M.M., Lu,J., Mount,D.B. and Delpire,E. (2001) Localization of the $\mathrm{K}^{+}-\mathrm{Cl}^{-}$cotransporter, $\mathrm{KCC} 3$, in the central and peripheral nervous systems: expression in the choroid plexus, large neurons and white matter tracts. Neuroscience, 103, 481-491.

Prichard,J.W., Gallagher,B.B. and Glaser,G.H. (1969) Experimental seizure-threshold testing with fluorthyl. J. Pharmacol. Exp. Ther., 166, 170-178.

Race,J.E., Makhlouf,F.N., Logue,P.J., Wilson,F.H., Dunham,P.B. and Holtzman,E.J. (1999) Molecular cloning and functional characterization of $\mathrm{KCC} 3$, a new $\mathrm{K}-\mathrm{Cl}$ cotransporter. Am. J. Physiol., 277, C1210-C1219.

Rivera,C., Voipio,J., Payne,J.A., Ruusuvuori,E., Lahtinen,H., Lamsa,K., Pirvola,U., Saarma,M. and Kaila,K. (1999) The $\mathrm{K}^{+} / \mathrm{Cl}^{-}$co-transporter $\mathrm{KCC} 2$ renders GABA hyperpolarizing during neuronal maturation. Nature, 397, 251-255.

Shapira,Y. and Cohen,T. (1973) Agenesis of the corpus callosum in two sisters. J. Med. Genet., 10, 266-269.

Simon,D.B., Karet,F.E., Hamdan,J.M., DiPietro,A., Sanjad,S.A. and Lifton,R.P. (1996a) Bartter's syndrome, hypokalaemic alkalosis with hypercalciuria, is caused by mutations in the $\mathrm{Na}-\mathrm{K}-2 \mathrm{Cl}$ cotransporter NKCC2. Nat. Genet., 13, 183-188.

Simon,D.B. et al. (1996b) Gitelman's variant of Bartter's syndrome, inherited hypokalaemic alkalosis, is caused by mutations in the thiazide-sensitive Na-Cl cotransporter. Nat. Genet., 12, 24-30.

Staak,R. and Pape,H.C. (2001) Contribution of $\mathrm{GABA}_{\mathrm{A}}$ and $\mathrm{GABA}_{\mathrm{B}}$ receptors to thalamic neuronal activity during spontaneous absence seizures in rats. J. Neurosci., 21, 1378-1384.

Steriade,M., Contreras,D. and Amzica,F. (1994) Synchronized sleep oscillations and their paroxysmal developments. Trends Neurosci., 17, 199-208.

Stobrawa,S.M. et al. (2001) Disruption of ClC-3, a chloride channel expressed on synaptic vesicles, leads to a loss of the hippocampus. Neuron, 29, 185-196.

Timofeev,I., Grenier,F. and Steriade,M. (2002) The role of chloridedependent inhibition and the activity of fast-spiking neurons during cortical spike-wave electrographic seizures. Neuroscience, 114, 11151132.

Völk1,H. and Lang,F. (2001) Electrophysiology of betaine transport in isolated perfused straight proximal tubule. Pflügers Arch., 442, 136140.

Wangemann,P. (2002) $\mathrm{K}^{+}$cycling and the endocochlear potential. Hear. Res., 165, 1-9.

Woo,N.S., Lu,J., England,R., McClellan,R., Dufour,S., Mount,D.B., Deutch,A.Y., Lovinger,D.M. and Delpire,E. (2002) Hyperexcitability and epilepsy associated with disruption of the mouse neuronal-specific $\mathrm{K}-\mathrm{Cl}$ cotransporter gene. Hippocampus, 12, 258-268.

Received February 5, 2003; revised August 14, 2003; accepted August 18, 2003 